\title{
The Influence of Product Innovation, Digital Marketing and Competitive Advantage in Improving the Marketing Performance of Small and Medium Industries in Bali
}

\author{
Ni Made Wisni Arie Pramuki ${ }^{*}$, Ni Putu Ayu Kusumawati ${ }^{2}$ \\ 1,2 Universitas Hindu Indoesia, Jalan Sangalangit Tembawu Denpasar 80361 \\ *wisniariepramuki@gmail.com
}

\begin{abstract}
This study aims to investigate the role of digital marketing in strengthening the relationship of product innovation to marketing performance through competitive advantage. The data were obtained using a survey approach to 196 Small Medium Industries (SMI) management respondents throughout Bali. The research hypothesis was tested using structural equation modelling with the help of Smart.PLS 3.0 software. The main finding is that all hypotheses can be tested for truth, that there is a direct influence relationship between product innovation, competitive advantage and digital marketing relationship with SMI marketing performance, then digital marketing is able to strengthen the relationship of product innovation in improving SMI marketing performance in Bali. In order for the relationship to product innovation to be real and stronger in marketing performance, the role of competitive advantage and digital marketing is important.
\end{abstract}

Keywords: product innovation, digital marketing, advantage competitive, marketing performance.

\section{INTRODUCTION}

Small and Medium Industries (SMI) as industrial suppliers are an important part of Indonesia's economic growth in general and especially Bali, which uses the tourism sector as the backbone of the economy. Despite the pressure from the impact of corona pandemic (Covid19), the industrial sector still contributed the most to "national gross domestic product" (GDP) structure up to $19.98 \%$ in the first quarter of 2020 . Based on mapping results of Indonesian Ministry of Industry, not all SME sector is under pressure from the Covid-19 pandemic. However, it's miles determined that there are SMI sectors that still have high demand and can streng then trade balance. According to Khayam, the mapping starts from small, medium to large scale industrial sector. In summary, $60 \%$ of industry suffer, $40 \%$ are moderate and high demand industries. This of course will cause pressure on industrial growth. With SMI still contributing to GDP, this proves that SMI still has "large proportion of the total number" of businessman in Indonesia (1).

Another impact that is felt from the Covid-19 pandemic is the increasingly intense pressure of business competition in an increasingly competitive market. The emergence competition at business world is something that can not avoided. With existence competition, companies are faced with various opportunities and threats both from within and outside country for exportoriented SMI. For this reason, every company is required always understand and understand what ishappening at market and what consumers want, as well as various changes in the business environment, resulting in various SMI business actors in Bali Province to always innovate in terms of strategies to improve marketing performance.

Marketing performance is one of the benchmarks for the success of a company. Marketing performance is said 
to be an achievement obtained by the company from the overall marketing process activities (2). The same thing is also conveyed by (3), marketing performance is measure company's success which is measured at a predetermined period time as the value of activities compiled and implemented to determine whether the strategy formulated and implemented is correct or vice versa. That to improve marketing performance by implementing various strategies by managing resources company to create competitive advantage (4). Consistent with this, various empirical evidence shows that to improve marketing performance of various industries by implementing product innovation development through competitive advantage $[(5) ;(6) ;(7)]$

However, different results were found direct relationship variables as a determinant of marketing performance. (8) found that product innovation had no direct effect at competitive advantage. This is due to the lack of knowledge of MSME managers regarding importance of innovating in products and services which makes MSME products unable to compete with their competitors. (9) states that competitive advantage is a condition that cannot be achieved by a company given the rapid changes in technology and competitive map, the only condition that can be achieved by a company is a temporary competitive advantage. (10) also succeeded in proving that there was an insignificant relationship between competitiveound that product innovation had no direct effect on competitive advantage.

This inconsistent relationship has created problems for SMI effort improve marketing performance that focuses on product innovation and competitive advantage. This can be justified, considering that the main focus of Barney's RBV theory (1991) is how companies manage their internal resources in creating competitive advantage, ignoring external environmental factors, in this case the transformation of digital marketing. To improve this relationship to make it more comprehensive, researchers include the role of digital marketing as a moderating variable. As (7) also suggests paying attention to external factors that are thought to have an impact on marketing performance. Empirical evidence is shown by (11) which states that to improve marketing performance for creative industry entrepreneurs who process waste and used goods in the city of Malang, it can be done by increasing the strategy for implementing digital marketing through intellectual capital.

\section{LITERATURE REVIEW}

\subsection{Product Innovation}

The similarity in appearance of similar products from competitors is a driving factor for product innovation, usually competing products appear without experiencing significant changes and even tend to be static. This situation can be profitable, because the competition arising from the emergence of competitor products can be overcome by making product innovations. (6) and (7) state that innovation is the successful application of creative ideas within the company. Innovation is a company mechanism to adapt to a dynamic environment. Therefore companies are required to be able to create new assessments, new ideas and offer innovative products and improve service performance that satisfy customers. Furthermore (8) states that innovation is a technique or product that uses new technology to make it more useful. Product innovation variables are formed by 2 dimensions, namely efficacy and efficiency (12).

\subsection{Competitive Advantage}

The concept of corporate competitive advantage has been developed from the generic strategy proposed by (4). Things that can indicate the variable of competitive advantage are a) imitability, namely how difficult it is for competitors to imitate the company's superiority, b) Durability, namely how long can the superiority of the strategic assets of the organization last and organizational success, and c) ease of equaling, namely how easily competitors match assets -Organizational strategic assets. The variable of competitive advantage in this study is measured by three dimensions, namely price advantage, product advantage and service advantage (13).

\subsection{Digital Marketing}

Digital technology has changed the way humans communicate, act and make decisions. Marketing activities cannot be separated from the influence of digital technology. The term digital-based marketing (digital marketing) has evolved from initially marketing goods and services using digital channels to a broader definition, namely the process of acquiring consumers, building consumer preferences, promoting brands, nurturing consumers, and increasing sales. (14) states that digital marketing is an activity, institution, and process that is facilitated by digital technology in creating, communicating, and conveying values to consumers and other interested parties. Furthermore (11) also defines digital marketing as the use of technology to assist marketing activities that aim to increase consumer knowledge by adjusting it to their needs. Digital marketing variables are measured by 3 indicators, namely websites, social networks and email (14) 


\subsection{Marketing Performance}

Marketing performance is one of the benchmarks for the success of a company. Marketing performance is said to be an achievement obtained by the company from the overall marketing process activities (2). The same thing is also conveyed by (3), which states that marketing performance is a measure of the company's success which is measured at a predetermined period of time as the value of activities that have been compiled and implemented to determine whether the strategy that has been formulated and implemented is correct or vice versa. That to improve marketing performance, it can be done by implementing various strategies by managing resources within the company in order to create competitive advantage (4). Marketing performance variables in this study are measured by three indicators, namely the sales growth of competitors, market share growth and industrial sales growth (13).

\subsection{Conceptual Framework and Hypotheses}

Based on the results of the investigation of the SME marketing phenomenon, especially in Bali province, it shows that there has been a decline in sales turnover due to the effects of the Covid-19 pandemic. Another phenomenon is that not all SMIs use a digital marketing system. The empirical findings show that there are inconsistent findings when SMI players focus on product innovation and competitive advantage to improve their marketing performance. The search results indicate that the marketing performance of SMI is still low. It is suspected that these findings are more focused on internal resource management, but have not paid attention to contextual factors, in this case digital marketing transformation. In the future, these findings can be linked to the performance of SMIs so that it is expected that good direct marketing performance will also improve SMI performance so that it can contribute to the national economy. The research conceptual framework can be presented in Figure 1 below:

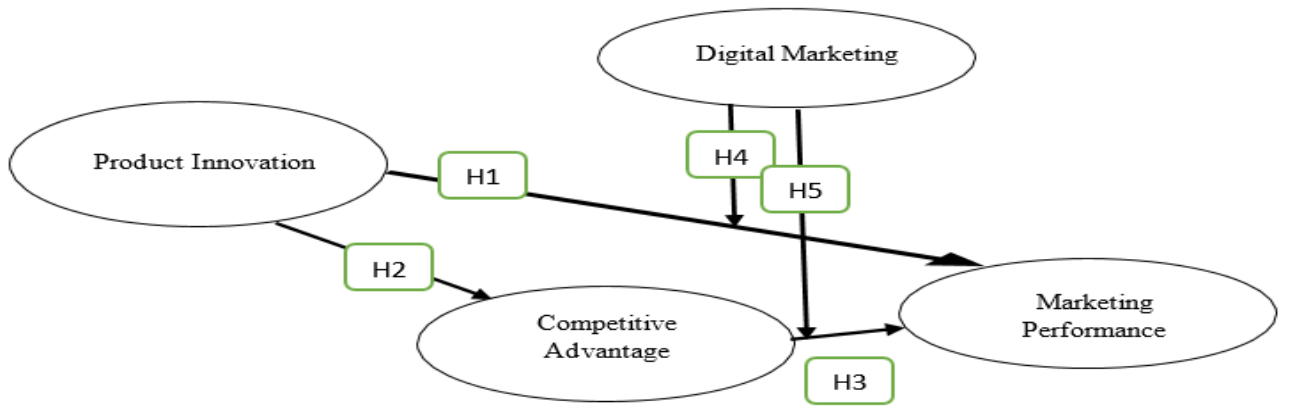

Figure 1. Conceptual Framework

Based on the theoretical description and previous research studies, the hypotheses that can be proposed in this study are:

H1. Product innovation has a positive and significant effect on marketing performance

H2. Product innovation has a positive and significant effect on competitive advantage

H3. Competitive Advantage has a positive and significant effect on marketing performance

H4. The interaction of digital marketing with product innovation can improve marketing performance

H.5 The interaction of digital marketing with competitive advantage can improve marketing performance

\section{METHOD}

This research is classified as an association research, which is to test how certain variables, in this case product innovation, competitive advantage and digital marketing, are able to provide variations in the improvement of SME marketing performance in Bali. This research was conducted using a survey method conducted at SMI throughout the province of Bali. The population in this study amounted to 464 SMI sectors. The sample size method used is the Slovin method with an error threshold of $5 \%$, so the recommended minimum sample size is 215 samples. The data analysis method used is to use a structural model equation approach with the help of Smart.PLS 3.0 software, on the grounds that this study 
wants to combine aspects of multiple regression (examining dependency relationships) and factor analysis to estimate a series of interrelated dependency relationships simultaneously (15).

\section{RESULTS AND DISCUSSION}

Data collection was carried out by distributing questionnaires which were distributed directly to respondents. A total of 250 questionnaires were distributed. Of these, 196 questionnaires were returned and complete so that they deserve further processing. Following are the results of the research using the Smart.PLS 3.0 software. Table 1 and Figure 2 show that the outer loading value is above 0.50 after previously obtained the results that there are still several indicators with a value below 0.50 so that it must be removed from the model and it is necessary to re-estimate it, so it can be said that all the indicators that form the dimensions or constructs is valid. Table 2 shows the AVE coefficient value is above $>0.50$, the value of Composite Reliability and Cronbach Alpha is also above 0.70 so it can be said that the indicators used in this study are reliable.

Table 1. Outer Loading

\begin{tabular}{|c|c|c|c|}
\hline Variabel & Indicator & Koefisien Outer Loading & P.Value \\
\hline \multirow{7}{*}{ Product Innovation } & E. 3 & 0,693 & 0,0000 \\
\hline & E. 4 & 0,698 & 0,0000 \\
\hline & E.5 & 0,73 & 0,0000 \\
\hline & E.6 & 0,787 & 0,0000 \\
\hline & IE. 5 & 0,698 & 0,0000 \\
\hline & IE.6 & 0,706 & 0,0000 \\
\hline & IE.7 & 0,678 & 0,0000 \\
\hline \multirow[t]{2}{*}{ Digital Marketing } & IP.1 & 1 & 0,0000 \\
\hline & KH.1 & 0,749 & 0,0000 \\
\hline \multirow{3}{*}{ Competitive Advantage } & КН.2 & 0,703 & 0,0000 \\
\hline & KP.3 & 0,816 & 0,0000 \\
\hline & KY.2 & 0,859 & 0,0000 \\
\hline Marketing Performance & P.1 & 1 & 0,0000 \\
\hline
\end{tabular}

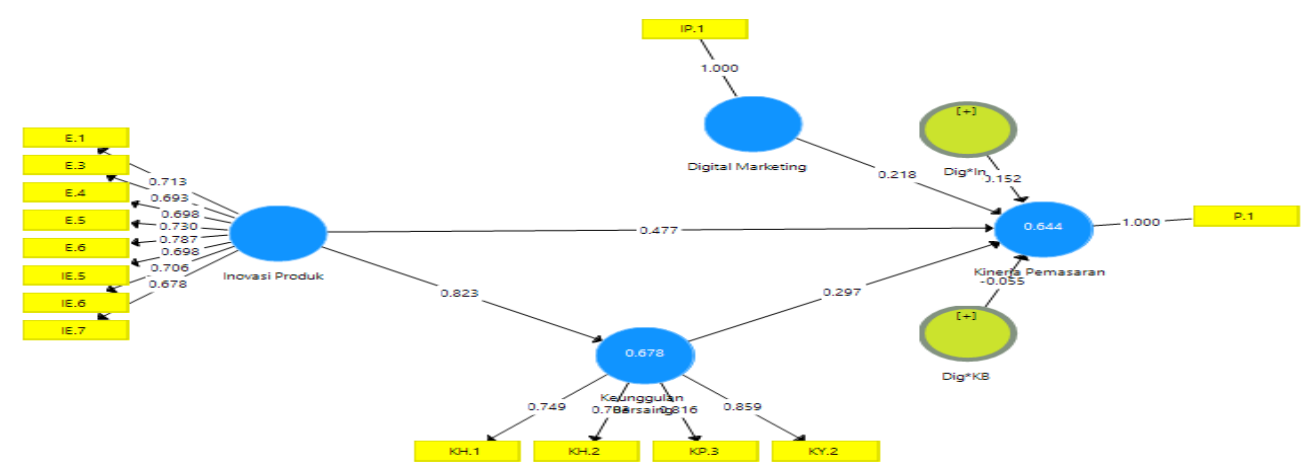

Fig 2. Structural Equation Model

Tabel 2. AVE, Composite Reliability, R-Square dan Cronbach Alpha

\begin{tabular}{lcccc}
\hline \multicolumn{1}{c}{ Variabel } & AVE & Composite Reliability & R-Square & Cronbach Alpha \\
\cline { 2 - 5 } Product Innovation & 0,509 & 0,892 & - & 0,862 \\
Digital Marketing & 1,000 & 1,000 & - & 1,000 \\
Competitive Advantage & 0,615 & 0,864 & 0,678 & 0,789 \\
Marketing Performance & 1,000 & 1,000 & 0,644 & 1,000 \\
\hline
\end{tabular}


Furthermore, the results of hypothesis testing can be explained in Figure 3 and table 3.

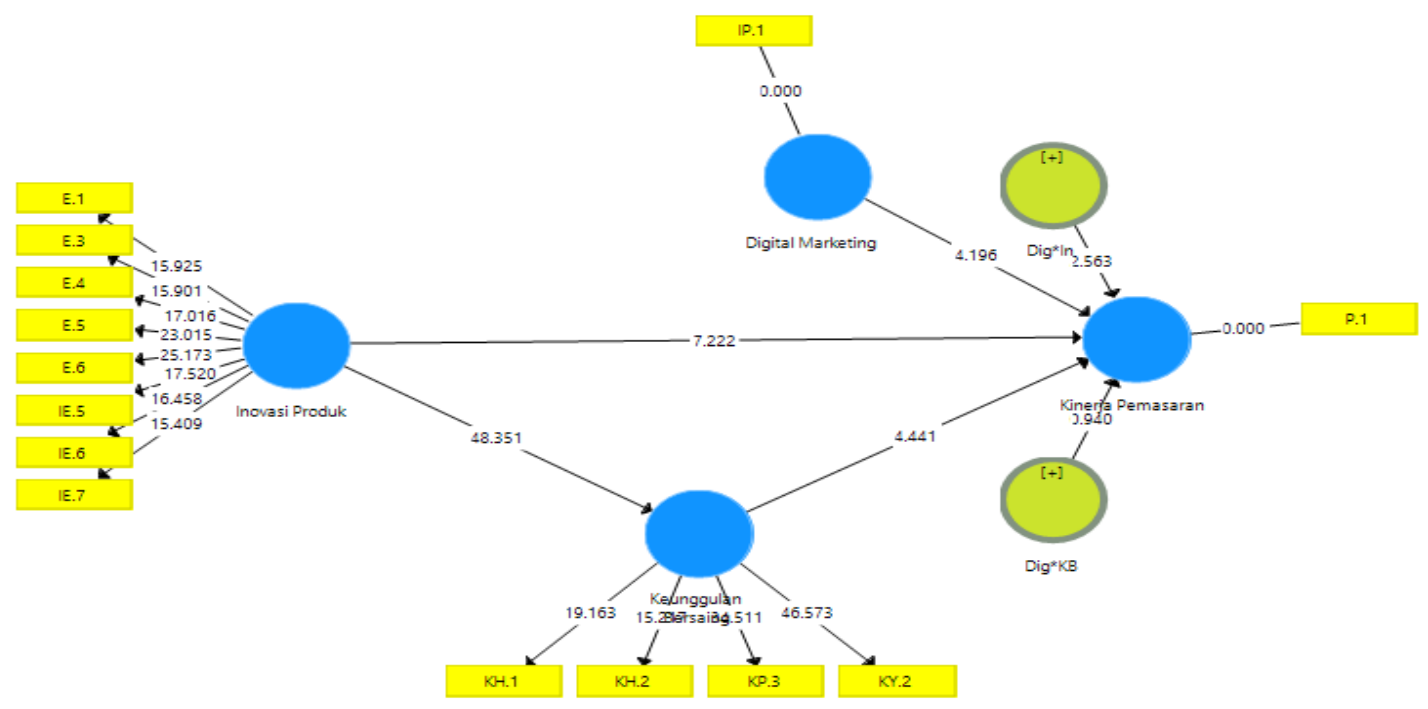

Fig 3. Path Anyalysis

Table 3 shows the direct relationship between the variables used in this study. Product innovation has a positive effect on 0.823 and has a significant relationship to competitive advantage with a statistical $t$ value of 48.351> t table 1.96, which means that Hypothesis 1 is statistically supported. This means that the increasing product innovation carried out by SMI business actors will automatically create a competitive advantage. The results of previous studies which are in line with this study emphasize that product innovation has a positive effect on competitive advantage which can be accepted and statistically proven in research $[(5) ;(6) ;(7)]$. That product innovation has a positive effect and has a significant relationship to competitive advantage.

Table 3. Hypothesis Test

\begin{tabular}{lccc}
\hline Pengaruh Antar Variabel & $\begin{array}{c}\text { Original } \\
\text { Sample } \\
(\mathrm{O})\end{array}$ & $\begin{array}{c}\text { T Statistics } \\
(|\mathrm{O} / \mathrm{STDEV}|)\end{array}$ & Remark \\
\hline Dig*In -> Marketing Performance & 0,152 & 2,563 & Signifikan \\
Dig*CA -> Marketing Performance & $-0,055$ & 0,940 & In-signifikan \\
Digital Marketing -> Marketing Performance & 0,218 & 4,196 & Signifikan \\
Produk Innovation -> Competitive Advantage & 0,823 & 48,351 & Signifikan \\
Produk Innovation -> Marketing Performance & 0,477 & 7,222 & Signifikan \\
Competitive Advantage -> Marketing Performance & 0,297 & 4,441 & Signifikan \\
\hline
\end{tabular}

\section{Source : Processed data}

Likewise, the effect of product innovation on SME marketing performance has a positive effect of 0.477 and has a significant relationship with the t statistical value of 7.222> t table 1.96, which means that Hypothesis 2 is statistically supported. This means that the more companies innovate in terms of the products they produce, it will also increase the marketing performance of SMIs. The results of previous studies which are in line with this study were stated by $[(5) ;(6) ;(7)]$ which states that product innovation has a positive and significant effect on marketing performance.

Furthermore, competitive advantage also has a positive effect of 0.297 and has a significant relationship with marketing performance with a statistical $t$ value of 4.441> t table 1.96, which means that Hypothesis 3 is supported. This means that there are variations of competitive advantage strategies, especially from the role of product innovation, then it can immediately improve marketing performance. The results of previous studies 
that are in line with this study were stated by $[(5) ;(6) ;(7)]$ which states that competitive advantage has a positive and significant effect on marketing performance.

Other results show when digital marketing acts as a moderating variable. That the role of digital marketing when interacting with product innovation has a positive effect of 0.152 and has a significant relationship to marketing performance with a statistical t value of 2.563> $\mathrm{t}$ table 1.96, which means that Hypothesis 4 is supported. This means that when there are still inconsistencies in the results of research on the direct effect of product innovation on marketing performance, the role of digital marketing as a moderating variable is needed so that it can improve marketing performance.

However, different results were found when the role of digital marketing interacts with competitive advantage, there is a negative effect of -0.005 and has an insignificant relationship with marketing performance with a statistical $t$ value of $0.940<\mathrm{t}$ table 1.96, which means that Hypothesis 5 is not supported. This means that when competitive advantage acts as a moderator for the effect of product innovation on marketing performance, the role of digital marketing is unable to improve or strengthen this relationship.

\section{CONCLUSION AND LIMITITATIONS}

Based on the overall research results, this research has theoretical and practical implications. Theoretically, this research has succeeded in proving the hypothesis regarding its direct influence on marketing performance such as product innovation, competitive advantage and digital marketing. These results indicate that the role of the variable product innovation, competitive advantage and digital marketing is very important in improving the marketing performance of SMEs, especially in the province of Bali. The competitive advantage variable is also able to clarify the relationship of product innovation to SMI marketing performance. Likewise, digital marketing variables when interacting with product innovation can improve marketing performance. However, other findings have not been successful in proving when the digital marketing variable interacts with competitive advantage in an effort to improve marketing performance. The practical implications of this research are that SME business actors in the province of Bali must pay more attention to marketing performance to sustain their business, especially during the Covid-19 pandemic and in the future which is influenced by product innovation factors to create competitive advantage by implementing digital marketing strategies. to expand its marketing area so that it will encourage an increase in marketing performance.

The limitation in this study is the elimination of many research indicators, presumably because of the large number of questionnaires that have not been returned so that it may affect the results of the study. For further research, it is suggested to expand the scope of research not only in the province of Bali but also to cover several provinces and also to expand the scope of variables such as intellectual capital and other contextual variables so that the research results can be generalized.

\section{ACKNOWLEDGMENTS}

The author would like to thank the Directorate General of Higher Education of the Indonesian Research and Technology Agency for fully funding this research through the Beginner Lecturer Research Grant scheme, all agencies and individuals who have provided moral and material support during the research implementation.

\section{REFERENCES}

[1] Agung Hidayat. Sektor industri menyumbang 19\% PDB Indonesia di kuartal pertama 2020. Kontan.co.id. 2020 May;

[2] Dewi NMP, Ekawati NW. Peran Keunggulan Bersaing Dalam Memediasi Pengaruh Orientasi Pasar Terhadap Kinerja Pemasaran. E-Jurnal Manaj Unud. 2017;6(9):4947-77.

[3] Pramuki NMWA. Antecedents of the Use of MSME Social Media:In The Perspective of Technology Acceptance Model Theory. Int J Contemp Res Rev. 2020;11(04):21776-86.

[4] Barney JAYB, Peng M. Resource-Based " View " a Useful Is the Resource-Based Perspective for Strategic Perspective for Management Management Research? Yes. Rev Lit Arts Am. 2001;26(1):41-56.

[5] Harjadi D, Fatmasari D, Nurhasanah AS. Market Orientation And Product Innovation To Increase Competitive Advantages And Its Impact On Marketing Performance. Al-Amwal J Ekon dan Perbank Syari'ah. 2020;12(1):12.

[6] Brahmanthara KA, Yasa NNK. Peran Keunggulan Bersaing Memediasi Inovasi Produk Terhadap Kinerja Pemasaran. Pros Semin Nas AIMI. 2017; Vol 8 No 1(1):50-67.

[7] Elfahmi SH, Jatmika D. Pengaruh Inovasi Terhadap Ukm Naik Kelas Melalui Daya Saing Produk. Media Mahard. 2019;17(3):481.

[8] Prabawati A, Handayani M. Orientasi Pasar Dan Inovasi Produk Pengaruhnya Terhadap Kinerja Pemasaran Dengan Variabel Intervening Keunggulan Bersaing Pada MSME Kecamatan Kaliwates. Maj Ilm “Dian Ilmu.” 2019;18(2):117.

[9] Oliver RW. Real Time Strategy: Sustainable 
Competitive Advantage? Journal of Business Strategy. 2000.

[10] Setyawati O:, Abrilia H. Pengaruh Orientasi Pasar Kewirausahaan dan Orientasi Pasar Terhadap Kinerja Perusahaan Melalui Keunggulan Bersaing dan Persepsi Ketidakpastian Lingkungan Sebagai Prediksi Bariable Moderasi. J Fokus Bisnis. 2013;12(02):20-32.

[11] Sidi AP, Yogatama AN. Mediasi Intellectual Capital atas Pengaruh Digital Marketing Terhadap Kinerja Pemasaran. Iqtishoduna. 2019;15(2):129.

[12] Alegre J, Lapiedra R, Chiva R. A measurement scale for product innovation performance. Eur $\mathrm{J}$
Innov Manag. 2006;

[13] Kaleka A, Morgan NA. Which competitive advantage (s)? Competitive advantage-market performance relationships in international markets. J Int Mark. 2017;

[14] Pradiani T. Pengaruh Sistem Pemasaran Digital Marketing Terhadap Peningkatan Volume Penjualan Hasil Industri Rumahan. J Ilm Bisnis dan Ekon Asia. 2018;11(2):46-53.

[15] Hair JF, Black WC, Babin BJ, Anderson RE. Multivariate Data Analysis Seventh Edition. Pearson New International. 2014. 